Modern Economy

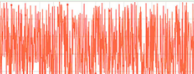

Journal of Modern Economy

(ISSN:2577-8218)

\title{
Foreign direct investment, Agriculture and economic growth: ARDL and causality approach for Rwanda
}

\author{
Xiaoling Yuan ${ }^{1}$, Michel Mivumbi $^{2^{*}}$ \\ ${ }^{1}$ Faculty, School of Economics and Finance, Xi'an Jiaotong University Shaanxi P.R.China. \\ ${ }^{2}$ Doctoral Researcher Applied Economics, School of Economics and Finance, Xi'an Jiaotong \\ University Shaanxi P.R.China.
}

\begin{abstract}
This study tested the relationship between Rwanda's economic ${ }^{*}$ Correspondence to Author: growth, foreign direct investment, and labor in agricultural Michel Mivumbi spanning between 1970 and 2017. In this paper, the ARDL Doctoral Researcher Applied Econ"bounds" test method is used to analyze the co-integration omics, School of Economics and problem of variables with a constant level relationship. Co- Finance, Xi'an Jiaotong University integration coefficients were estimated using the ARDLs Shaanxi P.R.China.

model. After verifying the long-term (co-integration) equilibrium relationship of economic growth within the variables, the error correction model is used to estimate the short-term coefficients. We found that agriculture and foreign direct investment have becomes an engine depending of Rwanda's economic development. The FDI has a causal relationship to economic growth; while labor have no causal relationship to economic growth. The Rwandan government should promote macroeconomic policies to encourage foreign direct investment 4:13. and promote economic growth in agriculture.

How to cite this article:

Xiaoling Yuan, Michel Mivumbi. Foreign direct investment, Agriculture and economic growth: ARDL and causality approach for Rwanda. Journal of Modern Economy, 2020;
\end{abstract}

Keywords: Foreign Direct Investment; Agriculture; ARDL Model; Bounds test; Economic growth

Bounds tes

eScîPub

eSciPub LLC, Houston, TX USA.

Website: https://escipub.com/ 


\section{Introduction}

FDI, agriculture and economic growth have the effect on Rwandan's population development. Recently, Rwanda's economic growth has been strong, and poverty has been eliminated by enhancing FDI in agriculture. Rwanda's agricultural sector is a major activity in all regions, with $80 \%$ of the Rwandan population participating in agriculture. The agricultural sector accounts for $33 \%$ of GDP and exports generate more than $45 \%$. Agriculture is also important for national food, but food crop production has always raising the agricultural sector (Gale, Tuan, Lohmar, Hsu, \& Gilmour, 2002). The total agricultural employment rate between 1991 and 2017 was $82.72 \%$. The ratio of agricultural value added to GDP is 42.79\% on average, from 1965 to 2017 (World Bank, 2011). Rwanda's FDI as a proportion of GDP has average value of $1.11 \%$ from 1970 to 2017. Agriculture, especially primary agriculture such as horticulture, crops growing and breeding as value added has become an attractive to foreign direct investments and economic growth development. Fishing, livestock and forestry caused by agriculture also contribute to the capital formation for FDI and economic growth. The link between agriculture, foreign direct investment, and economic growth of Rwanda is the focus in the study.

With steady economic growth over the past 20 years, the Rwandan government has worked hard to attract foreign direct investment to promote capital formation. To attract investors, Rwanda has carried out reforms, particularly to support investment and policy reforms to retain foreign investors. Rwanda's population density, is one of the most densely populated countries in sub-Saharan Africa, with 230 people per square kilometer (600 people per square mile). There are few villages in this country, and almost every family lives in a self-sufficient compound on the hillside. Rwanda's economy was hit hard by the 1994 genocide, a large number of people were killed, infrastructure was unmaintainable and looted, and important cash crops were ignored. This has led to a significant decline in GDP and undermined the country's ability to attract private and external investment. Since then, the economy has been strengthened, with GDP per capita (PPP) estimated at US \$ 2225 in 2018.

In 2012, agriculture accounted for $33 \%$ of Rwanda's economy. Rwanda has long relied on coffee as a cash crop. In 1989, the price of coffee plummeted, leading to a substantial decline in purchasing power and increased domestic tensions. The main export markets include China, Germany and the United States. Rwanda is a country with few natural resources, and its economy relies mainly on local farmers using simple tools to maintain their livelihoods. It is estimated that $90 \%$ of the working population was farms in 2010, and agriculture accounted for $42.0 \%$ of GDP. Encourage foreign direct investment in agriculture to use technologies and inputs. This paper aims to study relationship between FDI, agriculture, and economic growth in Rwanda, the well developing country, helps policy makers for making future plans not only for Rwanda but provides a reference for others African developing country.

\section{Literature review}

Literature review is including different study on the causal relationship between agricultural, foreign direct investment, and economic growth. Studies are categorized into the following topics.

\subsection{The relationship between agriculture and economic growth}

Many studies have shown that there is a link between agriculture and economic growth. Using the bounds testing, author (Oyakhilomen \& Zibah, 2014), indicate that agricultural production has a significant impact on the favorable trend of Nigeria 's economic growth. In order to alleviate rural poverty, we must increase investment in agricultural development.

Dethier \& Effenberger, (2012) found that in the next few years, agriculture is critical to improving food productivity, output and economic growth in developing countries, especially in small-scale farmers in sub-Saharan Africa. According to Jyun-Yi \& Chih-Chiang, (2008), the effective impact of agriculture on economic growth is achieved through the accumulation of domestic capit- 
al and knowledge.

After discussing the erroneous dichotomy of agricultural and industrial development, Clark \& Thorbecke, (1972) agreed that there was a mutual relationship between agricultural and industrial development in the course of economic growth. Singer \& Thorbecke, (1971) analysis found that agriculture is the engine of economic growth, and despite the significant increase in productivity, agriculture still experienced difficulties. According to Gollin, (2010), it is found that the growth of agricultural productivity has a significant impact on the economic growth of developing countries.

\subsection{The relationship between foreign direct investment and economic growth}

The relationship between foreign direct investment (FDI) and economic growth the author Belloumi, (2014) believes that, in the long run, when FDI is the dependent variable, the related benefit variables are bound together and the related equilibrium correction it is also significant, confirming the existence of a long-term relationship, and FDI has no significant Granger causality in the short term. Contrary the study of Karimi \& Yusop, (2009), found that in Malaysia, there is no strong evidence that there is a two-way causal and long-term relationship between foreign direct investment and economic growth. This shows that foreign direct investment has an indirect impact on Malaysia's economic growth. Research on Ibrahiem, (2015) reveals the existence of unidirectional causality from foreign direct investment to economic growth and supports hypothetical feedback. Sunde, (2017) pointed out that, contrary to some studies, foreign direct investment promoted economic growth, and the study found that foreign direct investment did not cause to economic growth. VECM-Granger causality analysis found that from foreign direct investment to economic growth, there is a one-way causal relationship between economic growth and foreign direct investment. This confirms South Africa's growth assumptions of foreign direct investment.

Authors Pradhan, Norman, Badir, \& Samadhan, (2013) confirmed that there is a two-way causal relationship between FDI and GDP. India needs to increase foreign direct investment and economic growth as a prerequisite for accelerating economic growth. Researcher lamsiraroj, (2016) pointed out that the overall effect of FDI is positively related to growth, and vice versa; this in turn further stimulates income growth, and the possibility of a two-way relationship between FDI and economic growth. Author Almfraji \& Almsafir, (2014) show that foreign direct investment and economic growth relationship are significantly positive. Scholar of Pegkas, (2015) shows that there is a positive long-term co-integration relationship between FDI stock and economic growth.

\subsection{The relationship between agriculture and foreign direct investment}

Scholars (Udemba, 2020), by using linear (ARDL) output, affirmed the positive and significant link between ecological footprint and agriculture, and the negative link between ecological footprint and foreign direct investment. Granger causality test shows that the unidirectional transmission of agriculture and foreign direct investment to the ecological footprint. Among them, the policy framework should focus on the use of energy and promote economic development through foreign direct investment and agriculture. Enilolobo, Mustapha, \& Ikechukwu, (2019) used autoregressive distribution lag error correction model estimation research to show that Nigeria's agricultural output lag in the current period is positive and significant. The Granger causality test revealed the two-way causality between $\mathrm{Ni}$ gerian agricultural output and FDI. Increasing agricultural output should become a strategic policy for attracting foreign investors.

Theorists Bayraktar-Sağlam \& Yetkiner, (2014) predict that foreign direct investment in agriculture may promote economic growth through technology transfer to poorer countries, a process that ensures spillover effects on the economy. Researchers Ben Slimane, HuchetBourdon, \& Zitouna, (2016) show that FDI is significant spillover effect in the agricultural. The author Suleman, (2009) agrees that at the core of any sustainable development and foreign 
direct investment, there is a relationship between the agricultural sector, and this relationship still exists when the opportunity to attract foreign direct investment into the agricultural sector is increased. Santangelo, (2018) believes that in addition to the positive spillover effect of foreign direct investment in the agricultural sector of developing countries, it also has a positive impact on food security by expanding land used for crop production. Epaphra \& Mwakalasya, (2017) believes that FDI inflows had no significant impact on the ratio of Tanzanian agricultural added value. Agriculture is one of the key points for developing countries; this is why most developing countries increase their agricultural productivity and development level by relaxing restrictions on foreign direct investment from domestic (Adegboye, Ojo, \& Oguninola, 2016).

\section{Methodology}

\subsection{Theoretical model}

The paper therefore transforms the Cobb Douglas production function into an aggregated production function displaying a relationship between GDP growth, FDI, and agriculture value, where coefficient caused by them indicate linkage relationship theoretical background.

\subsection{Autoregressive distributed lag model}

The empirical analysis of economic growth cointegration takes GDP growth as the natural logarithm, that is, InGDPG on the side of the dependent variable; the natural logarithm of foreign direct investment (InFDI) and the natural logarithm of agriculture $(\ln A)$ as independent variables. The analysis was done by using an ARDL model or "bounds" testing co-integration approach where confirmation of co-integrated leads to ARDL-ECM by (Pesaran, Shin, \& Smith, 2001). The reason for using ARDL in this study is that it is more suitable for small samples (Ghatak \& Siddiki, 2001), and whether the regression equation (independent variable) is I (0) co-integration or I (1) by (Pesaran, 2008) it can be applied. In the ARDL approach estimation is likely even when variables and optimal lags number are different. In the ARDL co-integration "bound" approach residual correlation is free and hence endogeneity problems is less (Pesaran \& Pesaran, 2016). This paper uses an ARDL model rather than a static model to capture all the dynamic responses brought by the lag change of the dependent variable itself, as well as the lag values and other explanatory variables. Starting with direct estimation of static long-term equations, it may not be possible to capture any immediate, short-term, and longterm responses in the system, resulting in inaccurate coefficient estimates (Banerjee, Gertler, Ghatak, Journal, \& April, 2002). Functional and econometric models are use variables in natural logarithms; and the coefficients of the co-integration vector are interpreted as long-term elasticity where the first difference is interpreted for all variables:

$$
\begin{aligned}
\Delta \ln g d p g_{t}= & C_{1}+\beta_{1} \ln g d p g_{t-1}+\alpha_{1} \ln f d i_{t}+\phi_{1} \ln A_{t}+\sum_{i=1}^{p} a_{11} \Delta \ln g d p g_{t-i}+\sum_{i=1}^{q} a_{21} \Delta \ln f d i_{t-i}+ \\
& \sum_{i=1}^{q} a_{31} \Delta \ln A_{t-i}+\varphi_{1 t}
\end{aligned}
$$

$$
\begin{aligned}
\Delta \operatorname{lnfdi}_{t}= & C_{2}+\beta_{2} \operatorname{lnfdi} i_{t-1}+\alpha_{2} \operatorname{lngdpg}_{t}+\phi_{2} \ln A_{t}+\sum_{i=1}^{p} a_{12} \Delta \ln g d p g_{t-i}+\sum_{i=1}^{q} a_{22} \Delta \ln A_{t-i}+ \\
& \sum_{i=1}^{q} a_{32} \Delta \ln f d i_{t-i}+\varphi_{2 t}
\end{aligned}
$$

$$
\begin{aligned}
\Delta \ln \mathrm{A}_{t}= & C_{3}+\beta_{3} \ln \mathrm{A}_{t-1}+\alpha_{3} \operatorname{lnfdi}_{t}+\phi_{3} \operatorname{lngdpg}_{t}+\sum_{i=1}^{p} a_{13} \Delta \ln g d p g_{t-i}+\sum_{i=1}^{q} a_{23} \Delta \ln A_{t-i}+ \\
& \sum_{i=1}^{q} a_{33} \Delta \ln f d i_{t-i}+\varphi_{3 t}
\end{aligned}
$$


The expected signs of these parameters are $\beta_{n}>0, \alpha_{n}>0, \phi_{n}>0, \varphi_{n t}<0$, the error term $\varphi_{n t}$ as for the examination of long-run equilibrium based on critical values is used with the null hypotheses and alternative hypotheses as; $H_{o}: \beta_{n}=\alpha_{n}=\phi_{n}=0$ no long-term relationship; while $H_{1}: \beta_{n} \neq \alpha_{n} \neq \phi_{n} \neq 0$ there is a long-term relationship. There are two steps involved in the ARDL estimation methods process. The first step is to test the existence of long-term equilibrium between variables by calculating the significance of the F-statistic and variable lag levels under the ARDL model. The second step is the long-term coefficient estimation in order to extrapolate its value. The econometric package used was Eview9 version. If there is no co-integration, the ARDL ( $p, q_{1}, q_{2}$ ) model (4-6) below will be specified:

$$
\begin{gathered}
\Delta \ln g d p g_{t}=a_{1}+\sum_{i=1}^{p} a_{1 i} \Delta \ln g d p g_{t-i}+\sum_{i=1}^{q} a_{2 i} \Delta \ln A_{t-i}+\sum_{i=1}^{q} a_{3 i} \Delta \ln f d i_{t-i}+e_{1 t} \\
\Delta \ln A_{t}=a_{2}+\sum_{i=1}^{p} a_{1 i} \Delta \ln A_{t-i}+\sum_{i=1}^{q} a_{2 i} \Delta \ln g d p g_{t-i}+\sum_{i=1}^{q} a_{3 i} \Delta \ln f d i_{t-i}+e_{2 t} \\
\Delta \ln f d i_{t}=a_{3}+\sum_{i=1}^{p} a_{1 i} \Delta \ln f d i_{t-i}+\sum_{i=1}^{q} a_{2 i} \Delta \ln g d p g_{t-i}+\sum_{i=1}^{q} a_{3 i} \Delta \ln A_{t-i}+e_{3 t}
\end{gathered}
$$

If there is co-integration, the error correction

(7-9) below as: model (ECM) representation is specifying model

$\Delta \ln g d p g_{t}=a_{1}+\sum_{i=1}^{p} a_{1 i} \Delta \ln g d p g_{t-i}+\sum_{i=1}^{q} a_{2 i} \Delta \ln A_{t-i}+\sum_{i=1}^{q} a_{3 i} \Delta \ln f d i_{t-i}+\lambda E C T_{t-1}+e_{1 t}$

$\Delta \ln \mathrm{A}_{t}=a_{2}+\sum_{i=1}^{p} a_{1 i} \Delta \ln A_{t-i}+\sum_{i=1}^{q} a_{2 i} \Delta \ln g d p g_{t-i}+\sum_{i=1}^{q} a_{3 i} \Delta \ln f d i_{t-i}+\lambda E C T_{t-i}+e_{2 t}$

$\Delta \ln f d i_{t}=a_{3}+\sum_{i=1}^{p} a_{1 i} \Delta \ln f d i_{t-i}+\sum_{i=1}^{q} a_{2 i} \Delta \ln g d p g_{t-i}+\sum_{i=1}^{q} a_{3 i} \Delta \ln A_{t-i}+\lambda E C T_{t-i}+e_{3 t}$

In the co-integration test, ECM is very important because it starts from the fact that if macroeconomic variables are zero-order I (0) integrals, that is, they are co-integrated, then they can be generated by ECM. The ECM aggregates this set of forecast data together in an economically meaningful way. The long-term model is then recompiled to ECM, which integrates the shortterm and residual terms (imbalances), ECT in the long-term relationship dynamics of the model in equation 7-9. Through the Granger causality test, determine whether the FDI lag value predicts changes in economic growth or explains the time path of economic growth. The test also estimated the significance of the F-statistic test for the lag on each of the right variables (Granger \& Granger, 2010). For two variables with different lag lengths, this study uses paired Granger causality tests to compare various combinations, and the maximum lag specification is 3 lags.

\subsection{Data and Variables Description}

Data for the gross domestic product growth (GDPG), Foreign Direct Investment (FDIs), and Agriculture value $(A)$ were drawn from World Bank national data and world development indicator. 


\begin{tabular}{lccc}
\hline & LNA & LNFDI & LNGDP \\
\hline Mean & 3.662861 & -0.341773 & 1.790606 \\
Median & 3.646089 & -0.215633 & 1.998485 \\
Maximum & 4.120969 & 1.467686 & 3.561730 \\
Minimum & 3.332474 & -3.601413 & -1.335342 \\
Std. Dev. & 0.241439 & 1.202475 & 0.843183 \\
Skewness & 0.337157 & -0.511198 & -1.391467 \\
Kurtosis & 2.223505 & 2.755034 & 6.488734 \\
Jarque-Bera & 1.762738 & 1.842171 & 33.19332 \\
Probability & 0.414215 & 0.398087 & 0.000000 \\
Sum & 146.5145 & -13.67094 & 71.62426 \\
Sum Sq. Dev. & 2.273412 & 56.39186 & 27.72735 \\
Observations & 40 & 40 & 40 \\
\hline
\end{tabular}

From table1 GDP growth rate used as a proxy of macroeconomic performance, InGDPG represents all goods and services that produced by country in period of one year having resolved for the double counting problem. The study used GDP per capita growth as natural logarithm at time $t$, as a measure of economic growth modeled as a dependent variable, (Rodríguez-Pose \& Tselios, 2010) found that the existing inequality level and the increase in regional income and education inequality have a significant positive correlation with subsequent economic growth. Independent variable is InFDI percentage of GDP at time $t$ as natural logarithm. According to the (Weltbank, 2015) acquisition of a permanent management control and a not less than $10 \%$ shareholding of an enterprise resident in a given country by an investor resident constitutes FDI in another country. FDI can be separated into flow and stock of FDI. Whereas FDI flow refers yearly inflows of foreign capital, stock of FDI is total value of capital owned by foreigners. Access to FDI inflows can help host countries create sustainable economic and productivity linkages. Natural logarithm of agriculture value as percentage of GDP $(\operatorname{InA})$; is defined as agriculture productivity, forestry, and fishing, as well as crops planting and livestock production with value added as percentage of GDP at $t$ time (FAO, 2012). (InGDPG), (InFDI), and (InA) are standardized by GDP to eliminate issues related to absolute measurement. Although a more economical model is preferred in econometric theory, this study's Solow model is used to avoid potential bias.

\section{Results}

\subsection{Regression Analysis of time series}

Time series regression analysis necessarily uses past data to quantify historical relationships. If the future is the same as the past, then these historical relationships are used to predict the future. However, if the future is radically different from the past, these historical relationships may not be a reliable guide to the future (J. Stock \& Watson, 2010). The ordinary least squares (OLS) method is commonly used to estimate the slope coefficients of autoregressive models to avoid non-stationary "false regression" invalid estimates. The use of OLS relies on a stationary random process. To estimate the slope coefficient, first perform a unit root test for stationarity testing. Then performed an augmented dickeyfuller (ADF) test on variables that followed the unit root process. The null hypothesis is that the variable contains a non-stationary unit root. The variable generates a stationary process by intercept and trend to avoid the unit root. When unit roots are detected at levels with intercepts and trends, the variables are the first differences from intercepts and trends until they become stationary. 
Table 2. ADF Unit Root Test results with intercept and trend

\begin{tabular}{cccccccc}
\hline Variable name & $\begin{array}{c}\text { ADF } \\
\text { test }\end{array}$ & $\begin{array}{c}\text { Lag Length } \\
\text { (AIC) }\end{array}$ & $\begin{array}{c}\mathbf{1 \%} \\
\text { Level }\end{array}$ & $\begin{array}{c}\mathbf{5 \%} \\
\text { Level }\end{array}$ & $\begin{array}{c}\mathbf{1 0 \%} \\
\text { Level }\end{array}$ & P-Value & Comment \\
\hline InGDPG/ & $-3.09 /$ & $8 /$ & $-4.80 /$ & $-3.79 /$ & $-3.34 /$ & $0.15 /$ & Non Stationary/ \\
$D(\operatorname{InGDPG})$ & -5.50 & 2 & -4.39 & -3.61 & -3.24 & 0.00 & Stationary \\
InFDI/ & $-2.21 /$ & $1 /$ & $-4.17 /$ & $-3.51 /$ & $-3.19 /$ & $0.47 /$ & Non Stationary/ \\
$D(\operatorname{InFDI})$ & -7.43 & 1 & -4.18 & -3.51 & -3.19 & 0.00 & Stationary \\
$\operatorname{InA} /$ & $-2.74 /$ & $0 /$ & $-4.17 /$ & $-3.51 /$ & $-3.18 /$ & $0.23 /$ & Non Stationary/ \\
$D(\operatorname{InA})$ & -7.49 & 0 & -4.17 & -3.51 & -3.19 & 0.00 & Stationary \\
\hline
\end{tabular}

*MacKinnon (1996) one-sided p-values.

Table 2 describes the ADF test when the variable is tested for the unit root with a trend term containing an intercept. The results show that all variables at this level are non-stationary. Therefore, the null hypothesis of non-stationary variables is not denied. Again, because when the test is performed at the first difference, all variables become stationary at $5 \%$ significance level. This conclusion is based on the comparison of statistical tests and tabulated critical values, that is, the variables are non-stationary when I (1) order integration. Therefore, the non-stationary null hypothesis is rejected. When ADF is performed on the variables, including the intercept and trend terms, the results are slightly different. As shown in Table2, non-stationary null hypothesis tests will be rejected. Now, after realizing that all the variables considered are non-stationary at their level, but after their first difference becomes stationary, the "bounds" test method will now be used to study the long-term equilibrium relationship in ARDL Co-integration is performed in the modeling method. Table3 below shows the results of co-integration as a bounds test between variables, and is regularized in ARDL under OLS regression. The critical values used in the F-statistic study are shown in table3 below, and different regression equations are calculated using the model at a constant level. According to $(\mathrm{J} . \mathrm{H}$. Stock \& Watson, 2017) and (Bahmani-Oskooee \& Ratha, 2004), in an uncertain situation, an effective way to establish co-integration is to apply the ECM version in the ARDL model. These thresholds include an upper bound and a lower bound, bringing all possible arrangements of variables into I (1) or I (0).

Table 3. F-statistic bounds test result with Constant level

\section{F-statistic}

$\begin{array}{lc}F_{\text {gdp }}(\operatorname{InGDPG} / \operatorname{lnfdi}, \operatorname{In} \mathrm{A}) & 10.72 \\ F_{\text {fdi }}(\ln F D I / \operatorname{lngdpg}, \ln \mathrm{A}) & 5.32 \\ F_{A}(\operatorname{InA} / \operatorname{lngdpg}, \ln F D I) & 1.61\end{array}$

\begin{tabular}{cccccc}
\hline Critical bounds value & \multicolumn{2}{c}{$\mathbf{5}$ percent } & \multicolumn{2}{c}{$\mathbf{1 0}$ percent } \\
\cline { 2 - 5 } & $\mathrm{I}(0)$ bound & $\mathrm{I}(1)$ bound & $\mathrm{I}(0)$ bound & $\mathrm{I}(1)$ bound \\
\hline & 3.79 & 4.85 & 3.17 & 4.14 \\
\hline
\end{tabular}

The F-statistic results in Table3 indicate that there is a long-range relationship between the dependent variable (GDP and FDI), and the independent variable in the co-integration equation. Calculated F-statistic 10.72 and 5.32 which are greater than critical values 3.79-4.85 at five percent level with constant level, confirm co-integration and existence of the long run relation- ship between dependent and independent variables as shown in table5. From this output the null hypothesis of no co-integration can be rejected and co-integration relationship exists along with growth economics (InGDPG), foreign direct investment (LnFDI) and agriculture value ( $\operatorname{LnA}$ ) as its determinants. Co-integration, of two variables at $5 \%$, confirms computing long-run 
and short-run coefficients by estimating long-run relationship with $A R D L$ and ECM modeling. Two steps to be estimated in ARDL and ECM modeling are; first long-term coefficients relationship within variables used which is determined by Ftest, second short-run relationship of variables with long-run elasticity (error correction term) representation of ARDL model. Akaike (AIC) information criterion, Hannan-Quinn (HQ) information criterion and Schwarz (SIC) information criterion are used to determine the lag order selection. As shown in table4, all of the above criteria have their lowest values at lag 1 , and extrapolation of endogenous variables helps to estimate the ARDL-ECM model used in equation (4).

Table 4. VAR ag Order Selection Criteria

\begin{tabular}{ccccccc}
\hline Lag & LogL & LR & FPE & AIC & SC & HQ \\
\hline 0 & -78.81806 & NA & 0.024705 & 4.812827 & 4.947506 & 4.858756 \\
1 & -22.38400 & $99.58951^{*}$ & $0.001522^{*}$ & $2.022588^{\star}$ & $2.561304^{*}$ & $2.206306^{*}$ \\
\hline
\end{tabular}

* Indicates the lag order selected by the condition

\subsection{ARDL-ECM Modeling}

Using the ARDL-ECM model, this article will use the ARDL and ECM models to estimate the longterm and short-term elasticity of FDI inflows and agriculture value to Rwanda's economic growth.
Due to sample size limitations, the maximum lag length is defined as one. Therefore, the longterm coefficients in equation 1 are estimated in table5. The lags are 1, 0, 1 corresponding to InGDPG, InA and InFDI.

Table 5. Long-run coefficients estimation using ARDL

\begin{tabular}{ccccc}
\hline \multicolumn{5}{c}{ Dependent Variable: InGDPG } \\
\hline Variable & Coefficient & Std. Error & t-Statistic & Prob. \\
\hline LNA & -2.80 & 0.82 & -3.43 & 0.002 \\
LNFDI & -0.29 & 0.18 & -1.63 & 0.114 \\
C & 11.81 & 2.94 & 4.02 & 0.000 \\
\hline
\end{tabular}

As shown in table5 the long-term coefficients of agriculture and foreign direct investment are 2.80 and -0.29 , respectively, meaning that agricultural value increased by $1 \%$, economic growth was $2.80 \%$, and foreign direct investment increased by $1 \%$ the economic growth was $0.29 \%$. At a significance level of $1 \%$, the longterm effects of FDI and agriculture on economic growth are gradual. The results are in line with Rwanda's growth assumptions that rely on agriculture and foreign direct investment. At the same time agricultural value is a driving factor for economic development. The results of the short-term dynamic coefficient and long-term equilibrium relationship calculated by ECM model equation (7) are shown in table6. The ECM model passed all tests. The impact of agricultural value and FDI levels on growth economics is gradual and the impact of agricultural value on growth economics in the short-term relationship is continuous. Agriculture grew by $1 \%$ and growth economics incline by $0.77 \%$; foreign direct investment increased by $1 \%$, economic growth decline $-0.50 \%$. Short-term coefficients of agriculture value are larger than the long-term coefficients. This shows that changes in agricultural production have had a strong impact in the long term. In the short run, the impact of FDI on growth economics is also declining, which means that dependence has decreased in the short term, which may be due to the application of aid inflows and the optimization of donors; therefore, FDI should be encouraged in economic growth Inflow. The ECM coefficient is very significant with the correct sign, which means that the system has the ability to converge to a long-term equilibrium after a short-term shock. With a value of -0.76 , about $76 \%$ of the 
imbalance can be adjusted next year. This means that the GDP imbalance will converge within a year. $R^{2}$ as the coefficient of determination for short-run dynamics in table6 appears to influence GDP growth, where $\left(R^{2}\right)$ at 0.57 , variations in $D(\ln G D P G)$ can explain $57 \%$ of changes for a short run in all variables InFDI and InA for the period of study. The implication is that $43 \%$ is explained by other factors, not covered in the study.

Table 6. Error Correction Model Specification for Selected ARDL Model

Dependent Variable: D (InGDPG)

Method: Least Squares

\begin{tabular}{ccccc}
\hline Variable & Coefficient & Std. Error & t-Statistic & Prob. \\
\hline C & 0.142029 & 0.127823 & 1.111138 & 0.2771 \\
D (LNGDP (-1)) & 0.015185 & 0.163061 & 0.093127 & 0.9265 \\
D (LNA (-1)) & 0.770443 & 1.790280 & 0.430348 & 0.6706 \\
D (LNFDI (-1)) & -0.497751 & 0.134785 & -3.692928 & 0.0011 \\
ECM (-1) & -0.755313 & 0.230739 & -3.273448 & 0.0031 \\
\hline R-squared & 0.572193 & Mean dependent var & 0.017002 \\
Adjusted R-squared & 0.503744 & S.D. dependent var & 0.881774 \\
S.E. of regression & 0.621170 & Akaike info criterion & 2.036588 \\
Sum squared resid & 9.646301 & Schwarz criterion & 2.270120 \\
Log likelihood & -25.54881 & Hannan-Quinn criter. & 2.111297 \\
F-statistic & 8.359389 & Durbin-Watson stat & 1.828041 \\
Prob(F-statistic) & 0.000200 & & & \\
\hline
\end{tabular}

The value of the Durbin Watson statistic of the dependent variable in table 6 is show no spurious in this regression of the study. In addition, the diagnostic test of the LM sequence correlation test in table7 shows that the model has no autocorrelation problem due the probability of the F-statistic is greater than 0.05 , making 0.39 > 0.05 . This will lead to a short-term relationship between economic growth, FDI and agriculture.

Table 7. Breusch-Godfrey Serial Correlation LM Test

\begin{tabular}{cccc}
\hline F-statistic & 0.98 & Prob. F (2,23) & 0.39 \\
Obs $^{*}$ R-squared & 2.35 & Prob. Chi-Square (2) & 0.31 \\
\hline
\end{tabular}

Furthermore table8 as heteroskedasticity test show that the model is free from the problem of autocorrelation as the probability of Chi square and F-statistic is above 0.05 such that $0.86>0.05$, and $0.89>0.05$ respectively. Model is good and also confirms short-run relationship of FDI, agriculture and economic growth.

Table 8. Heteroskedasticity Test: Breusch-Pagan-Godfrey

\begin{tabular}{llll}
\hline F-statistic & 0.281 & Prob. F (4,25) & 0.89 \\
Obs*R-squared & 1.291 & Prob. Chi-Square (4) & 0.86 \\
Scaled explained SS & 1.494 & Prob. Chi-Square (4) & 0.83 \\
\hline
\end{tabular}

4.3 Diagnostic and Parameter Stability Tests Therefore, in figure (a)\&(b), it is important for us (Hansen, 1992) warns that estimated parame- to perform parameter and stability tests, beters of time series data may change over time. cause unstable parameters may lead to 
incorrect description of the model. (Pesaran, 2008) recommends that we always use the accumulation and test of recursive residuals. Both figures (a) and (b) are limited to the 5\% critical range of parameter stability. This means that we believe that the estimated parameters are stable.
Both the CUSUM test and the CUSUMQ test confirm the long-term equilibrium between agriculture, foreign direct investment and economic growth, and the residuals enhance the stability of the co-integration relationship, as shown in the following figure.

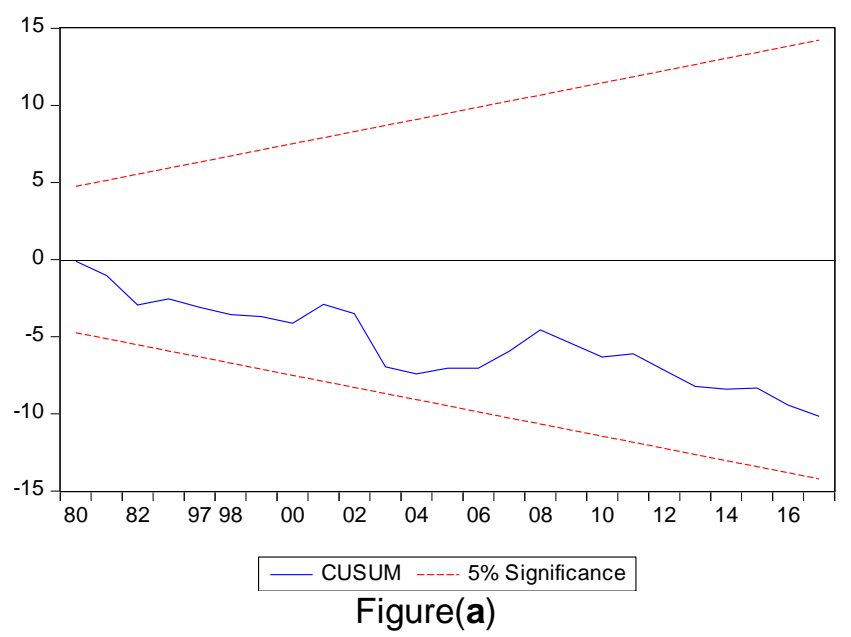

Figure. (a) Cumulative sum of Recursive Residuals;

\subsection{Granger Causality Result}

In table9, the Granger causality test is performed at a lag of 2 to predict the past and future. If the probability of any given combination of the two variables is less than $5 \%$, there is a rejection of the null hypothesis, which results in the existence of the two variables. The result of rejecting

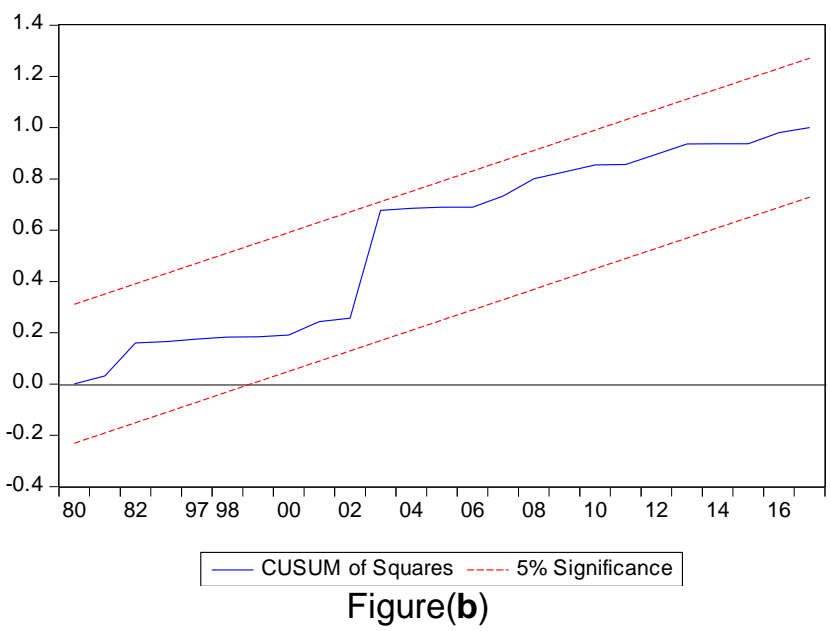

(b) Cumulative Sum of Squares of Recursive Residuals InFDI is less than $5 \%$ at its $p$ value of 0.01 this means that FDI common Granger causes economic growth at a one-way causality, where agriculture common caused economic growth at $10 \%$ at $p$ value of 0.09 .

Table 9. Pairwise Granger Causality Tests

\begin{tabular}{cccc}
\hline Null Hypothesis: & Obs & F-Statistic & Prob. \\
\hline LNFDI does not Granger Cause LNA & 46 & 1.80 & 0.18 \\
LNA does not Granger Cause LNFDI & & 0.08 & 0.93 \\
LNGDP does not Granger Cause LNA & \multirow{2}{*}{30} & 2.55 & 0.09 \\
LNA does not Granger Cause LNGDP & & 1.25 & 0.30 \\
LNGDP does not Granger Cause LNFDI & \multirow{2}{*}{30} & 0.81 & 0.46 \\
LNFDI does not Granger Cause LNGDP & & 5.78 & 0.01 \\
\hline
\end{tabular}

The causality shown in table9 means that through economic growth in agricultural value affects domestic investment. Evidence shows that foreign investment has an important role in promoting economic growth. There is a causal relationship from FDI to InGDPG from one direction of movement, which means that foreign investment leads to economic growth, which stimulates domestic investment growth in agriculture. This shows that whether the agricultural investment or a foreign investment, it has made a crucial contribution to promoting economic growth in receiving foreign direct investment. According to Singh (2010), based on the study of the long-term equilibrium and short-term dynamic relationship between India's service industry and gross domestic product (GDP), cointegration was established using the optimal single equation and maximum likelihood system estimation relationship. The authors found that m/journal-of-modern-economy/ 
the estimates of long-term elasticity parameters are statistically significant and that there is dimensional consistency between the estimates. The traditional cumulative sum (CUSUM) and new cumulative sum (CUSUM) and moving sum (MOSUM) tests show the stability of the equilibrium residuals and strengthen the co-integration relationship between model sequences. (Singh, 2010) found that the error correction model provides some support for the one-way Granger causality between service industries and GDP. The steady growth of the services sector is essential to absorb the adverse effects of weather shocks from agriculture and industry and provide elasticity to the economy (Singh, 2010).

\section{Conclusions \& Recommendation}

The overall objective of this study is to attempt an empirical analysis of Rwanda's GDP growth rate, foreign direct investment and agricultural over the period 1970-2017 dynamic relationship. In theory, the inflow of foreign direct investment, if properly managed, is expected to increase the growth rate of GDP, and agriculture will also increase, although this depends on the nature of the expenditure. In addition, although many empirical studies have assumed that agriculture also increase GDP growth. In this study, the ARDL-ECM model was used, and Rwanda's time series data were used for co-integration. This article takes the GDP growth rate as the dependent variable and uses it as an indicator of growth economics. In addition, the natural logarithm of agricultural and the natural logarithm of FDI are used as independent variables. Eviews 9 is the software used in this study. The research results show that when the system is disturbed (unbalanced), the system parameters are quite stable, and the system caused by the ECM returns to an equilibrium state at a speed of about $75 \%$. Based on the "bound" test results, a study showed that InGDPG is actually integrated with independent variables. This suggests that there is a long-term dynamic between capital growth and other explanatory variables. In addition, the results of the Granger causality test show that most of the questions and assumptions are reliable, which means that the explanatory vari- ables have predictive power for Rwanda's GDP growth. The Rwandan government should promote macroeconomic policies to encourage foreign direct investment and promote economic growth in agriculture. This is because FDI and agriculture variables have an effective / influence on GDP growth.

Further estimate the Granger causality of the key variables in the study to determine the direction of its causality. The research results show that FDI and agriculture have a significant impact on economic growth. An in-depth understanding of FDI behavior is of great significance to the sustainable development of FDI. Empirical analysis shows that more domestic efforts are essential to increase foreign direct investment inflows. Granger causality analysis shows that the pull effect of FDI on agriculture is the Granger effect. Therefore, policies that promote macroeconomic stability and investment must be adopted. However, the challenge of providing skilled agriculture must be overcome in order to achieve, through appropriate foreign direct investment policies, economic growth that is vital to improving the lives of the Rwandan people. Governments should pay more attention to the possible crowd-out effects of domestic investment, just as growth provides important intuition. This can create a competitive advantage and benefit from spillover effects. Rwanda should have the ability to absorb advanced agricultural technologies to take full advantage of foreign direct investment. Foreign direct investment has a positive effect on Rwanda's prosperity and economic growth. Restriction policies must guarantee overall economic benefits. The activities of multinational corporations have promoted economic growth in host countries. Therefore, in Rwanda, more incentives should be provided to foreign companies in countries seeking foreign direct investment to support sustainable agricultural in economic growth.

\section{References}

[1] Adegboye, F. B., Ojo, J. A. T., \& Ogunrinola, I. I. (2016). Foreign direct investment and industrial performance in Africa. Social Sciences (Pakista- 
n). https://doi.org/10.3923/sscience.2016.5830. 5837

[2] Almfraji, M. A., \& Almsafir, M. K. (2014). Foreign Direct Investment and Economic Growth Literature Review from 1994 to 2012. Procedia - Social and Behavioral Sciences.

https://doi.org/10.1016/j.sbspro.2014.03.668

[3] Bahmani-Oskooee, M., \& Ratha, A. (2004). The J-curve: A literature review. Applied Economics. https://doi.org/10.1080/0003684042000201794

[4] Banerjee, A. V, Gertler, P. J., Ghatak, M., Journal, S., \& April, N. (2002). Empowerment and Efficiency : Tenancy Reform in West Bengal. Journal of Political Economy, 110(2), 239-280. https://doi.org/10.1086/338744

[5] Bayraktar-Sağlam, B., \& Yetkiner, H. (2014). A Romerian contribution to the empirics of economic growth. Journal of Policy Modeling. https://doi.org/10.1016/j.jpolmod.2014.01.001

[6] Belloumi, M. (2014). The relationship between trade, FDI and economic growth in Tunisia: An application of the autoregressive distributed lag model. Economic Systems. https://doi.org/10.1016/j.ecosys.2013.09.002

[7] Ben Slimane, M., Huchet-Bourdon, M., \& Zitouna, H. (2016). The role of sectoral FDI in promoting agricultural production and improving food security. International Economics. https://doi.org/10.1016/j.inteco.2015.06.001

[8] Clark, C., \& Thorbecke, E. (1972). The Role of Agriculture in Economic Development. Econometrica. https://doi.org/10.2307/1913193

[9] Dethier, J. J., \& Effenberger, A. (2012). Agriculture and development: A brief review of the literature. Economic Systems. https://doi.org/10.1016/j.ecosys.2011.09.003

[10] Enilolobo, O. S., Mustapha, S. A., \& Ikechukwu, O. P. (2019). Nexus between Agriculture and Unemployment in Nigeria. Journal of Economics, Management and Trade. https://doi.org/10.9734/jemt/2019/v22i530103

[11] Epaphra, M., \& Mwakalasya, A. H. (2017). Analysis of Foreign Direct Investment, Agricultural Sector and Economic Growth in Tanzania. Modern Economy.

https://doi.org/10.4236/me.2017.81008

[12] FAO. (2012). Identifying opportunities for climate-smart agriculture investments in Africa. Food and Agriculture Organization of the United Nations.

[13] Gale, F., Tuan, F., Lohmar, B., Hsu, H. H., \& Gilmour, B. (2002). China's food and agriculture: Issues for the 21st century. USDA Economic Research Service.

[14] Ghatak, S., \& Siddiki, J. U. (2001). The use of the ARDL approach in estimating virtual exchange rates in India. Journal of Applied Statistics.

https://doi.org/10.1080/02664760120047906

[15] Gollin, D. (2010). Chapter 73 Agricultural Productivity and Economic Growth. Handbook of Agricultural Economics. https://doi.org/10.1016/S1574-0072(09)04073-0

[16] Granger, C. W. J., \& Granger, C. W. J. (2010). Investigating Causal Relations by Econometric Models and Cross-Spectral Methods. In Essays in Econometrics.

https://doi.org/10.1017/cbo9780511753978.002

[17] Gunasekera, D., Cai, Y., \& Newth, D. (2015). Effects of foreign direct investment in African agriculture. China Agricultural Economic Review. https://doi.org/10.1108/CAER-08-2014-0080

[18] Hansen, B. E. (1992). Testing for parameter instability in linear models. Journal of Policy Modeling. https://doi.org/10.1016/0161-8938(92)90019-9

[19] lamsiraroj, S. (2016). The foreign direct investment-economic growth nexus. International Review of Economics and Finance.

https://doi.org/10.1016/j.iref.2015.10.044

JME: https://escipub.com/journal-of-modern-economy/ 
[20] Ibrahiem, D. M. (2015). Renewable Electricity Consumption, Foreign Direct Investment and Economic Growth in Egypt: An ARDL Approach. Procedia Economics and Finance. https://doi.org/10.1016/s2212-5671(15)01299-x

[21] Jyun-Yi, W., \& Chih-Chiang, H. (2008). Does foreign direct investment promote economic growth? Evidence from a threshold regression analysis. Economics Bulletin.

[22] Karimi, M. ., \& Yusop, Z. (2009). FDI and Economic Growth in Malaysia. Munich Personal RePEc Archieve.

https://doi.org/10.5897/JAERD12.088

[23] Oyakhilomen, O., \& Zibah, R. (2014). Agricultural production and economic growth in Nigeria: Implication for rural poverty alleviation. Quarterly Journal of International Agriculture.

[24] Pegkas, P. (2015). The impact of FDI on economic growth in Eurozone countries. Journal of Economic Asymmetries.

https://doi.org/10.1016/j.jeca.2015.05.001

[25] Pesaran, M. H. (2008). An Autoregressive Distributed-Lag Modelling Approach to Cointegration Analysis. In Econometrics and Economic Theory in the 20th Century: The Ragnar Frisch Centennial Symposium. https://doi.org/10.1017/ccol0521633230.011

[26] Pesaran, M. H., \& Pesaran, M. H. (2016). Unit Roots and Cointegration in Panels. In Time Series and Panel Data Econometrics. https://doi.org/10.1093/acprof:oso/9780198736912.003.0031

[27] Pesaran, M. H., Shin, Y., \& Smith, R. J. (2001). Bounds testing approaches to the analysis of level relationships. Journal of Applied Econometrics. https://doi.org/10.1002/jae.616

[28] Pradhan, R. P., Norman, N. R., Badir, Y., \& Samadhan, B. (2013). Transport Infrastructure, Foreign Direct Investment and Economic Growth Interactions in India: The ARDL Bounds JME: https://escipub.com/journal-of-modern-economy/
Testing Approach. Procedia - Social and Behavioral Sciences.

https://doi.org/10.1016/j.sbspro.2013.11.186

[29] Rashid, I. M. A., Bakar, N. A., \& Razak, N. A. A. (2016). Determinants of Foreign Direct Investment (FDI) in Agriculture Sector Based on Selected High-income Developing Economies in OIC Countries: An Empirical Study on the Provincial Panel Data by Using Stata, 2003-2012. Procedia Economics and Finance. https://doi.org/10.1016/s2212-5671(16)30331-8

[30] Rodríguez-Pose, A., \& Tselios, V. (2010). Inequalities in income and education and regional economic growth in western Europe. Annals of Regional Science.

https://doi.org/10.1007/s00168-008-0267-2

[31] Santangelo, G. D. (2018). The impact of FDI in land in agriculture in developing countries on host country food security. Journal of World Business.

https://doi.org/10.1016/j.jwb.2017.07.006

[32] Singer, H. W., \& Thorbecke, E. (1971). The Role of Agriculture in Economic Development. The Economic Journal.

https://doi.org/10.2307/2229883

[33] Singh, T. (2010). Services sector and economic growth in India. Applied Economics. https://doi.org/10.1080/00036840802360229

[34] Stock, J. H., \& Watson, M. W. (2017). Twenty Years of Time Series Econometrics in Ten Pictures. Journal of Economic Perspectives. https://doi.org/10.1257/jep.31.2.59

[35] Stock, J., \& Watson, M. (2010). Forecasting with Many Predictors. Handbook of Economic Forecasting.

[36] Suleman, A. (2009). Fostering FDI in the agriculture sector. Pakistan Development Review. https://doi.org/10.30541/v48i4iipp.821-838

[37] Sunde, T. (2017). Foreign direct investment, exports and economic growth: ADRL and causality 
analysis for South Africa. Research in Interna-

tional Business and Finance.

https://doi.org/10.1016/j.ribaf.2017.04.035

[38] Udemba, E. N. (2020). Mediation of foreign direct investment and agriculture towards ecological footprint: a shift from single perspective to a more inclusive perspective for India. Environmental Science and Pollution Research. https://doi.org/10.1007/s11356-020-09024-4
[39] Weltbank. (2015). Foreign direct investment, net inflows/ net outflows, World Bank Data.

[40] World Bank, W. B. (2011). World Development Report 2011. Development, 2011(April), 416. https://doi.org/10.1596/978-0-8213-8439-8

[41] [dataset] World Development Indicators 2018; https://data.worldbank.org/country/rwanda?view=chart, API_RWA_DS2_en_excel_v2_511875

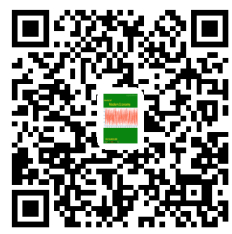

